R.E. Page, Jr., is Professor of Entomology, Department of Entomology, UC Davis.

The author thanks the many people who have been involved in the research summarized above, especially Kim Fondrk, Bernhard Kraus, Ernesto Guzmán-Novoa, Dave Nielsen, Scott Kinnee, Paul Ebert, David Chance and Mike Crosland. This research has been funded primarily by contracts from the California Department of Food and Agriculture, the Almond Board of California, and the California State Beekeepers Association.

\section{References}

Guzmán-Novoa E., Page RE. 1994a. The mpact of africanized bees on Mexican beekeeping. Am Bee J 134: 101-6.

Guzmán-Novoa E, Page RE. 1994b. Morphometric techniques do not detect intermediate and low levels of africanization in honey bee (Apis mellifera L.) colonies. Ann Entomol Soc Am 87: 507-15

Guzmán-Novoa E, Sanchez A, Page RE, Garcia T. 1996. Susceptibility of European and Africanized honeybees (Apis mellifera L.) and their hybrids to Varroa jacobsoni Oud. Apidologie 27: 93-103

Hall HG, Muralidharan K. 1989. Evidence from mitochondrial DNA that African honey bees spread as continuous maternal lineages. Nature 339: 211-13.

Hall HG, Smith DR. 1991. Distinguishing African and European honeybee matrilines using amplified mitochondrial DNA. Proc Nat Acad Sci USA 88: 4548-52.

Kraus B, Page RE. 1995a. Effect of Varroa jacobsoni (Mesostigmata: Varroadae) on feral Apis mellifera (Hymenoptera: Apidae) in California. Environ Entomol 24: 1473-80.

Kraus B, Page RE. 1995b. Population growth of Varroa jacobsoni Oud in Mediterranean climates of California. Apidologie 26 149-57.

Moretto G, Gonçalves LS, De Jong D, Bichuette MZ. 1991. The effects of climate and bee race on Varroa jacobsoni Oud infes. tations in Brazil. Apidologie 22: 197-203

Moretto G, Gonçalves LS, De Jong D. 1993. Heritability of Africanized and European honeybee defensive behavior against the mite Varroa jacobsoni. Braz J Genet 16 $71-7$

Page RE. 1992. How Africanized bees will affect California agriculturé. Cal Ag 46:18-19.

Rinderer TE, Buco SM, Rubink WL, Daly HV , Stelzer JA, Riggio RM, Baptista FC 1993. Morphometric identification of Africanized and European honey bees using large reference populations. Apidologie 24: 569-85.

Smith DR, Taylor OR, Brown WM. 1989 Neotropical Africanized honey bees have African mitochondrial DNA. Nature 339: 213-15.

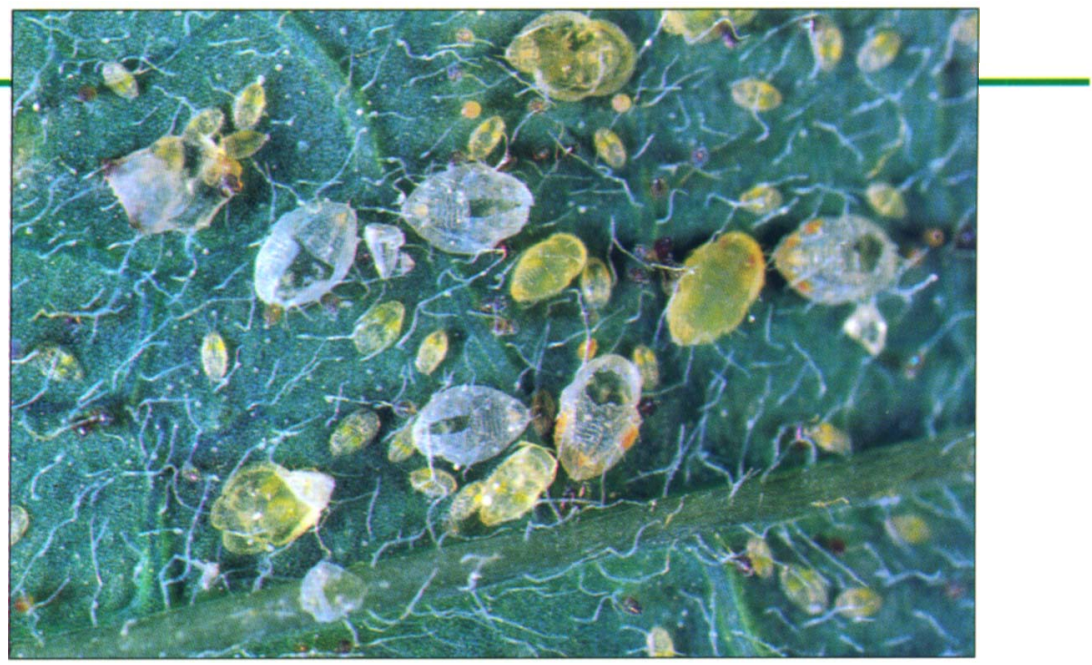

Exotic species invade the state continually. Two which have exacted high tolls are sweetpotato whitefly and silverleaf whitefly; nymphal stages of both are shown above.

\title{
Invasion biology: Rethinking our response to alien species
}

\author{
Robert C. Venette $\square \quad$ James R. Carey
}

Invasion biology is the study of the reproduction, dispersal and ecological impact of organisms that occur outside of their native range, including exotic pests and biological control agents. Alien species cost California agriculture billions of dollars annually in control measures and crop damage. Societal trends toward increased travel and import of plant and animal products suggest that exotic species will continue to enter California. Understanding the principles of the invasion process will help to predict which species will invade, where invaders will become established, and the effects of invasions on agricultural, urban and natural environments. Improved understanding of the invasion process should contribute to public policies designed to prevent or contain invasions, especially of potential pests that are not yet in the state and whose biology is poorly described.
More species are invading California today than at any other time in the state's history. Currently, more than 2,300 exotic species reside in the state, including 1,025 plants, 42 freshwater fish, 11 mammals, 9 birds and 208 invertebrates. While most introduced organisms fail to become established, those that do can become serious pests in agriculture, urban areas and natural landscapes. Alien species cost California agriculture billions of dollars annually in control measures and crop damage. In addition to their economic impact, some exotic organisms may threaten human health, displace native species or degrade environmental aesthetics. Consequently, many growers, conservationists, researchers and regulatory agencies share a similar commitment to mitigating and preventing unwanted invasions.

Recent efforts sponsored by UC in cooperation with the California Department of Food and Agriculture (CDFA) have inspired novel concepts about the processes that underlie both successful and unsuccessful invasions. 


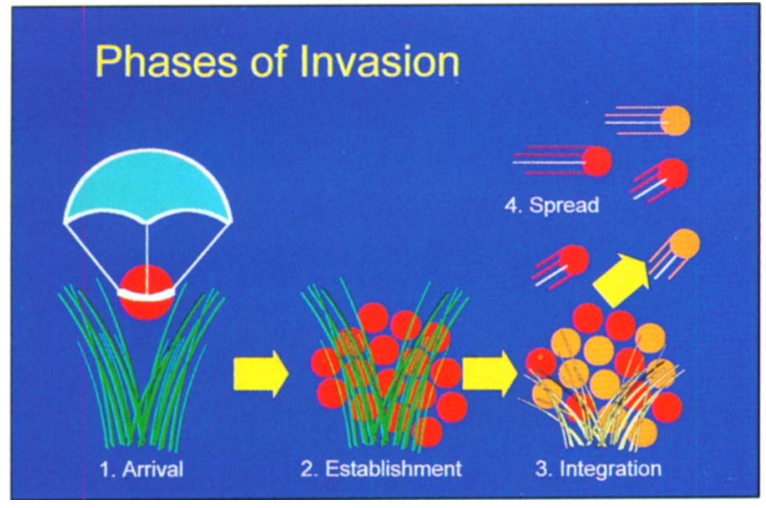

Fig. 1. Conceptual diagram of the invasion process. Different colored circles and plants appearing during the integration stage reflect ecological and evolutionary changes in the resident and exotic species as both groups of species adapt to one another.

Experiences with particular invaders (for instance, plants, insects and fish) have stimulated new hypotheses that apply to the invasions of many other species. Some of these insights have been presented at grower and academic conferences sponsored by UC Riverside and UC Davis. As our awareness of the invasion process continues to unfold, policymakers can refine existing strategies to prevent the introduction and spread of non-native species.

Fundamentally, invasion biology is the study of organisms that occur outside of their native range. The science applies to both pests and nonpests (for instance, biological control agents) and encompasses a wide diversity of organisms from fungi and plants to nematodes and mammals.

\section{Four stages of invasion}

Regardless of the organisms involved, all invasions progress through four fundamental stages: arrival, establishment, integration and spread (fig. 1; Vermeij 1996). After arriving, for example, in contaminated seedlots or "hitchhiking" on transported material, an introduced organism must reproduce in its new habitat to become established. Integration occurs as resident plants and animals adjust eco- logically and evolutionarily to the newcomers and as invaders adapt to local environmental conditions. The exotic organisms' dispersal throughout the new environment is driven by natural forces such as wind or rain, or by the need to find food supplies. Species that cannot complete all four stages are unlikely to become "invasive."

Research in the discipline of invasion biology tends to revolve around three central questions. Which species are likely to invade and become pests? Where will invasions be successful? How do invasions progress and how do they affect local communities? These questions are not new but still lack satisfactory answers (Rejmanek 1996; Williamson 1996).

\section{Species likely to invade}

Which species are likely to invade and become pests? Species that maintain high rates of growth, maturation and reproduction over a wide range of environmental conditions are more likely to become established once introduced into a new habitat (Venette 1997). For example, the widespread distribution of the ash whitefly (Siphoninus phillyreae) in California is due in part to its broad physiological tolerance: the ash whitefly reproduces and develops between $50^{\circ}$ and $86^{\circ} \mathrm{F}$ $\left(10^{\circ}\right.$ and $\left.30^{\circ} \mathrm{C}\right)$ and utilizes several plant species as hosts.

The genetics of a species may also contribute to invasiveness. For instance, organisms with small genomes (the number of genes within a cell) tend to be more successful invaders in disturbed habitats (Rejmanek 1996). In addition, resident populations of related native organisms that are already adapted to local climatic conditions may serve as conduits for the invasion of exotic biotypes. Biotypes are genetically and physiologically distinct subgroups within a species.

The invasion by the Africanized honey bee (Apis mellifera scutellata)

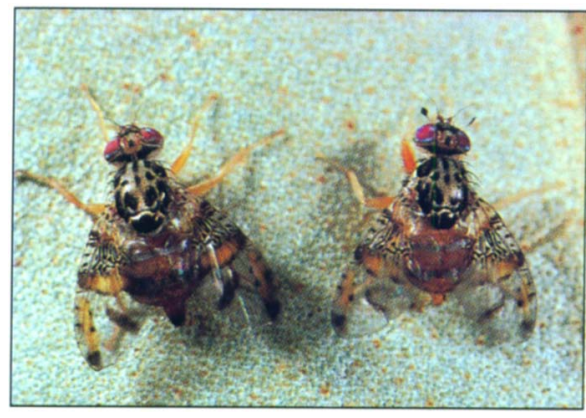

Some exotic species can be beneficial. The imported parasitic wasp Aphytis melinus parasitizes California red scale, which attacks citrus trees.

provides an interesting example of genetic invasion. Africanized bees hybridize with European honey bees (Apis mellifera), which are common throughout the western hemisphere. As a result, when the Africanized strains were accidentally released in Brazil, their "aggressive" genes genes that make honey bees behave aggressively - may have invaded resident European honey bee populations. Genetic invasions may occur more rapidly than species invasions and could explain how the Africanized bee spread more 6,000 miles from Sao Paulo, Brazil, to Southern California in less than 40 years (Moller 1996).

\section{Conditions conducive to invasion}

Invasions are most likely to succeed in sites that are highly disturbed or have a mild climate (Moyle and Light 1996). Disturbance remains difficult to define in absolute terms, but often reduces the number of established predators or increases the availability of resources per individual. For example, clearcutting forests reduces competition for soil nutrients and increases the amount of light available to an invader. The mild climate and rapid urbanization of Southern and coastal California make these regions of the state especially vulnerable to invasion. For example, in San Francisco County, which is coastal, $41 \%$ of the vascular plant species are exotic whereas in Lassen National Park, 


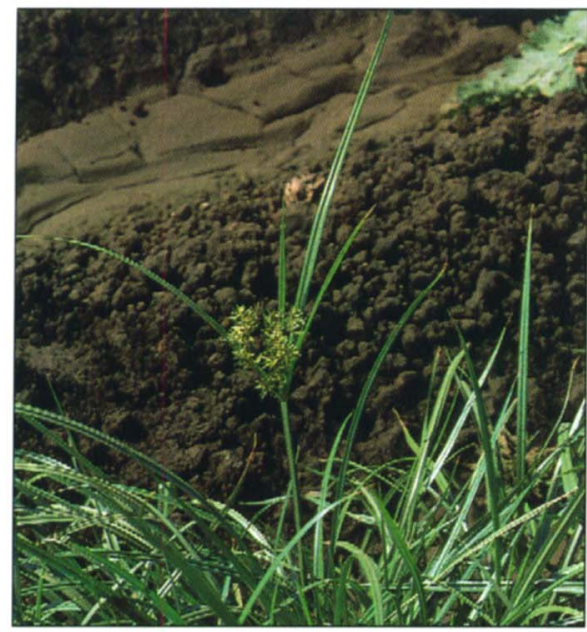

which lies inland, only $5 \%$ are exotic (Mooney et al. 1986).

The initial phases of invasion may proceed for much longer than is often estimated. It is common to assume that invaders arrived shortly before their initial detection (less than 5 years). In reality, due to inherent inefficiencies of any sampling strategy, invading populations may remain at low densities for decades without being detected (Carey 1996). For instance, Mediterranean fruit flies could have arrived well before the first specimens were trapped in 1975. Furthermore, if established in California, medflies most likely occur in small, sparse populations. The mere presence of an exotic pest does not automatically mean that a crisis is at hand. The long initial phases of invasion suggest that exotic pests might be suppressed through traditional IPM strategies but not necessarily eradicated to maintain crop production levels.

Following the arrival and establishment of exotic species, invasions may progress for decades or centuries, as demonstrated by the invasions of yellow starthistle (Centaurea solstitialis) and the walnut husk fly (Rhagoletis completa). Although yellow starthistle was first detected in California in 1869 and walnut husk fly in the 1920s, both pests continue to spread into new areas of the state. Similarly, the presence of gypsy moth in Southern California may simply represent the final stages

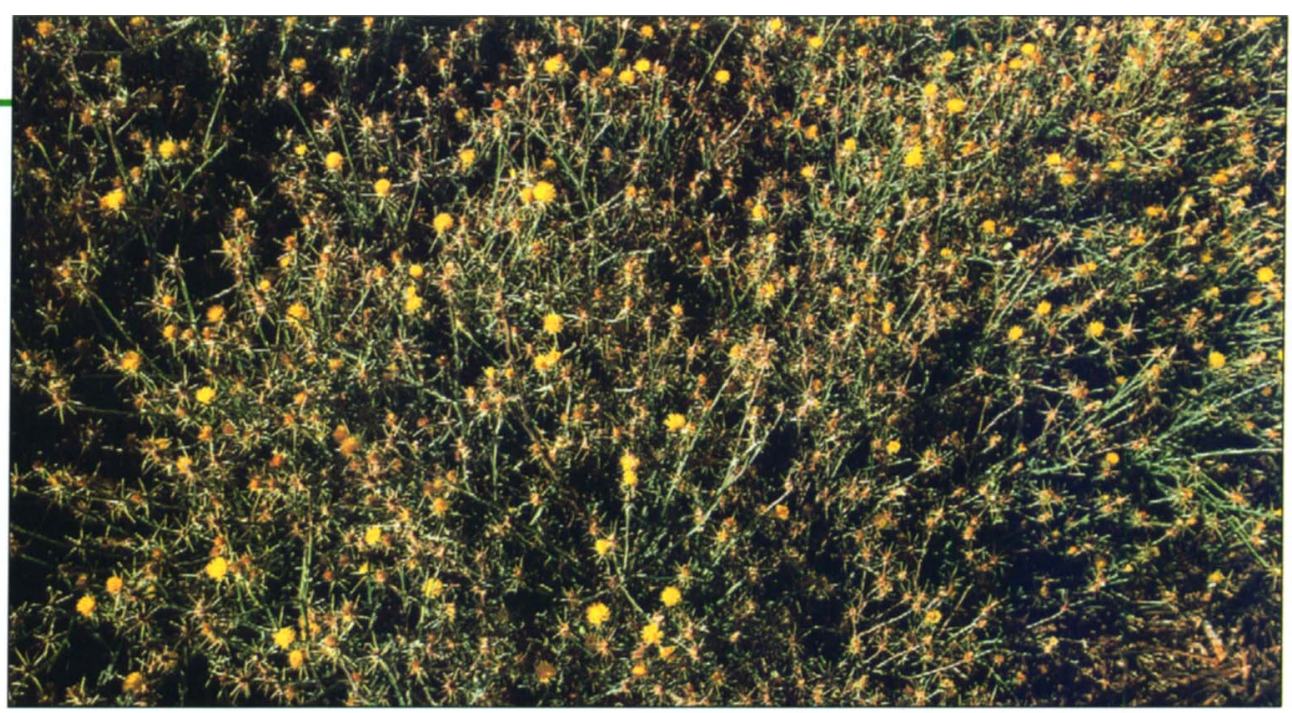

Yellow nutsedge, left, is a persistent pest of many crops. Yellow starthistle, right, first detected in California in 1869, continues to spread into new areas of the state, displacing native plant species. The establishment of alien plants has slowed, but overall invasions of nonnative species will continue, aided by importation of farm commodities and human travel.

of its North American invasion, which began in 1869.

Finally, not all invasions will have adverse effects, nor will the effects be uniformly distributed throughout an area. Even when potentially severe pests invade, their distribution and impact vary in response to host and climate suitability. For instance, if the medfly invaded California completely, the impact would be heavier in the Los Angeles Basin and lighter in the northeast and Sierra Nevada regions of the state (Carey 1996).

\section{Further study needed}

Despite these principles of invasion, our understanding of the nature of invasions is far from complete. How will exotic species affect ecosystems? What is the best way to describe and predict the pattern of spread? Must invaders adapt to local environmental conditions? Are there preconditions for eradication to be successful? Answers to these questions are especially important when developing response plans for recently introduced species. Ideally, answers would be based on broadly applicable principles of invasion.

Other agricultural sciences have already benefited from the development of general principles for their disciplines. For example, principles of crop and livestock breeding, plant and animal disease epidemiology, and postharvest treatments provide re- searchers and regulators with the basis to plan future activities, to evaluate the success of those actions, and to explain counterintuitive results. The concepts can be fine-tuned for special cases, but the fundamentals apply to all species.

Unfortunately, no unifying science exists to use as the foundation for research or public policies dealing with invasions. General principles describing the process of invasion are poorly defined partly because exotic species have been studied on a case-by-case basis (Vermeij 1996). Obviously, each introduced plant, animal and pathogen is unique in many ways. However, the processes underlying the invasions of such diverse organisms may be quite similar. Revealing similarities among invaders is at least as important as studying the biology and control of the individual pests themselves. Finding these similarities could lead to a broader notion of the invasion process and the development of general principles of invasion. Better theories of the invasion process may help growers, conservationists, researchers and regulatory agencies prepare for future invasions.

As general theories evolve that pertain to each stage of invasion, invasion biologists must make a concerted effort to apply those theories to agricultural issues. In particular, an improved understanding of the invasion process will prove essential to preclude and/ 


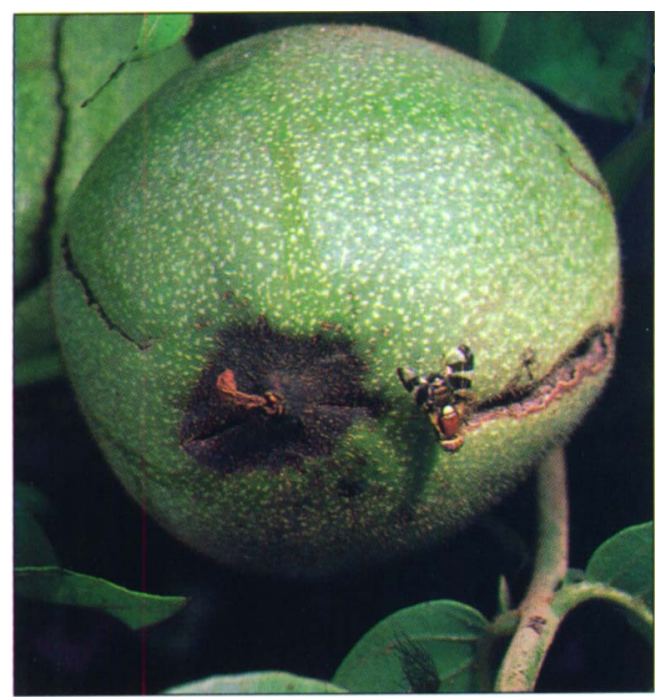

Following the arrival and establishment of exotic species, invasions may progress for decades or centuries, as demonstrated by the walnut husk fly.

or manage the future onslaught of invaders into California. Although the rate of establishment by alien plants in California may have slowed in the past 25 years (Rejmanek and Randall 1994), preventing and/or controlling the invasions of all non-native species will be a greater challenge.

Undoubtedly, established protocols for studying and controlling exotic pests have restricted the introduction and spread of many alien species. However, revisions to these policies may be necessary due to several national and statewide trends.
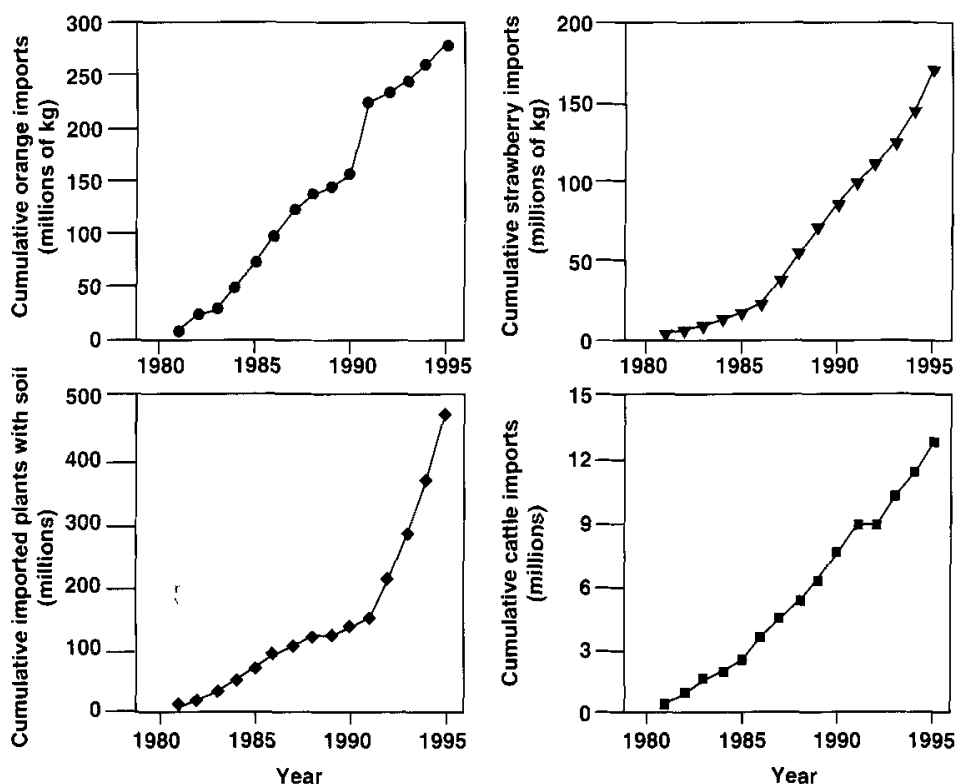

Fig. 2. Cumulative U.S. imports of select agricultural commodities since 1981 (Source: Census Bureau, U.S. Department of Commerce).

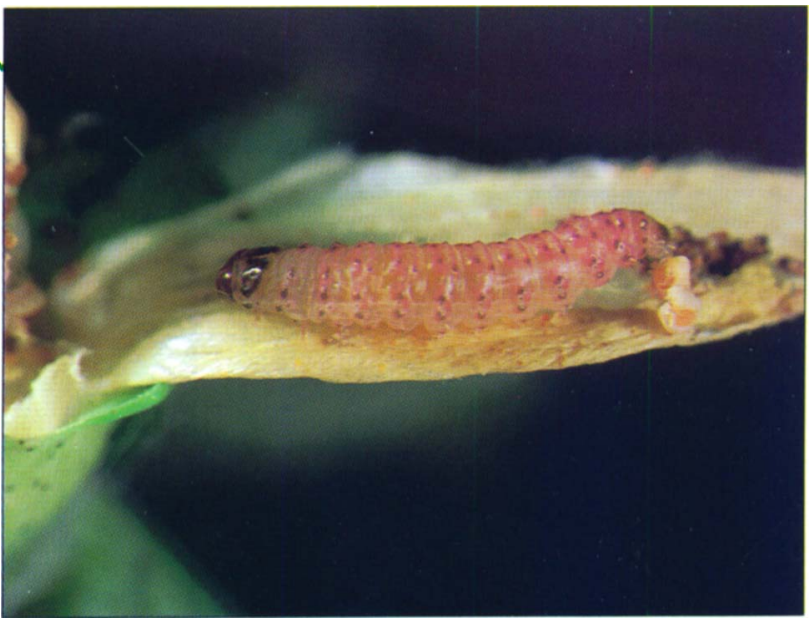

Growers have disrupted the invasion of pink bollworm with cultural practices including harvesting early, shredding cotton stalks and burying debris. Releases of sterile moths by CDFA and USDA-APHIS contribute to areawide management of the pest.

hicles entered California through 28 border stations. By 1992 the number had jumped to more than 25 million vehicles passing through 16 stations (CDFA 1994). By 2007 an estimated 750 million people will travel via plane (fig. 3). But is it feasible to inspect every person or shipment that enters the state for foreign organisms? Obviously time and limited resources prevent a complete inspection of everyone.

\section{Revisiting prevention strategies}

How much risk do the organisms that might not be intercepted pose to the state, and would the risks decrease substantially if more funds were allocated for inspections? Maintaining zero tolerance for certain pests may not be necessary because most inva-

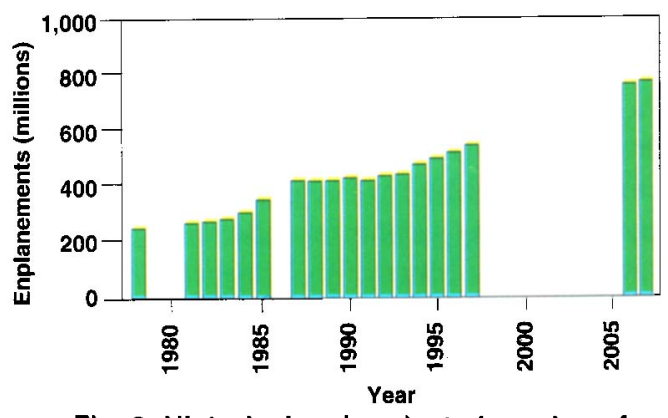

Fig. 3. Historical and projected number of annual enplanements, people boarding aircraft, in the United States (Source: Federal Aviation Administration-data not available for some years.). 
sions fail. In fact, experiences with trying to introduce species for biological control have shown that it is extremely difficult to get a successful "invasion" even if the invaders are carefully selected. While the odds of successful invasion are likely to increase as the "dose" of invaders increases, if a species is introduced below a critical density then those individuals are likely to die due to local antagonists (such as predators or species that compete for resources), environmental fluctuations, and demographic risks (for example, ending up with a population composed of males).

How could monitoring for exotic pests be improved? Trapping strategies should lure and/or immobilize active individuals more effectively and must consider where a pest will occur, when a pest is likely to be most abundant, and how a pest is likely to behave in various environments (Prokopy 1995). For example, medfly traps placed in citrus trees that have been stripped of fruit are less likely to be effective because flies are drawn elsewhere in search of food.

Experience with the medfly demonstrates the need for, and value of, genetic repositories for introduced organisms. Genetic analysis of preserved specimens may be the only way to determine how many times a pest has been introduced into California, the country where those individuals originated, or the "relatedness" of multiple outbreaks (Roderick 1996).

In addition to genetic data, the locations where pests are found provides valuable information on the course of an invasion. These detection and interception records should be analyzed with Geographic Information Systems (GIS), which can map the proximity of detections in space and time as well as highlight areas within the state that are prone to invasion. GIS applied to interception records might identify regions from which the state receives an inordinate number of non-native plants and animals.

Finally, how do we know when a pest has been eradicated? Failure to detect a pest following a control mea- sure (for instance, aerial spraying, release of biocontrol agents, sterile insect technique [SIT]) does not necessarily indicate that the measure was effective. Populations of many organisms fluctuate in response to climatic changes and may be eliminated by harsh weather. Alternatively, control attempts may simply drive pest numbers below detection thresholds rather than exterminate the population. Strict criteria to verify eradication are essential to determine whether particular control strategies are worth pursuing. Overestimating the effectiveness of control measures may partially account for the gypsy moth's successful invasion from Massachusetts to California, despite repeated claims that the pest had been exterminated or contained (Gerardi and Grimm 1979).

As society continues to change, traditional methods for managing exotic species may no longer be sufficient. The history of invasions indicates that organisms that do not pose a problem in their native ranges can be devastating in a new habitat. But, is it practical to guard against the arrival of every exotic organism, especially when resources to prevent, control and study invasions are not increasing? Given that time and money are limited and that the number of introduced species continues to increase, the study and control of invaders cannot be sustained on a case-by-case basis. Policies for the exclusion and management of exotic species will benefit from current and future developments in the discipline of invasion biology.

R.C. Venette is formerly Postdoctoral Fellow, Department of Nematology, UC Davis (currently Postdoctoral Associate, Department of Entomology, University of Minnesota, St. Paul, MN 55108) and J.R. Carey is Professor, Department of Entomology, UC Davis.
Exotic pests will not necessarily have the same effects in all areas. For instance, if the medfly invaded California completely, its impact would be heavier in the Los Angeles Basin and lighter in the northeast and Sierra Nevada regions.

\section{References}

Carey JR. 1996. The incipient Mediterranean fruit fly population in California: Implications for invasion biology. Ecology 77:1690-7.

CDFA [California Department of Food and Agriculture.1994. Report of the Blue Ribbon Panel on Future Strategies for Pest Exclusion in California. Sacramento: CDFA. 133 p. Gerardi MH, Grimm JK. 1979. The History, Biology, Damage, and Control of the Gypsy Moth, Portheria dispar (L.). Rutherford,

$\mathrm{NJ}$ : Farleigh Dickinson University Press. $233 \mathrm{p}$ Moller H. 1996. Lessons for invasion theory from social insects. Biological Conservation 78:125-42.

Mooney HA, Hamburg SP, Drake JA. 1986. The invasions of plants and animals into California. In: Mooney HA, Drake JA (eds). Ecology of Biological Invasions of North America and Hawaii. New York: Springer-Verlag. p. 250-74

Moyle PB, Light T. 1996. Fish invasions into California: Implications for invasion biology. Ecology 77:1666-70.

Prokopy RJ. 1995. Impact of Medfly foraging behavior on trapping and eradication. In: Morse JG, Metcalf RL, Carey JR, Dowell RV (eds). The Mediterranean Fruit Fly in California: Defining Critical Research. University of California, Riverside: College of Natural and Agricultural Sciences. p 109-22.

Rejmanek M. 1996. A theory of seed plant invasiveness: The first sketch. Biological Conservation 78:171-81.

Rejmanek M, Randall JM. 1994. Invasive alien plants in California: 1993 summary and comparison with other areas in North America. Madrono 41:161-77.

Roderick GK. 1996. Geographic structure of insect populations: Gene flow, phylogeography, and their uses. Annual Review of Entomology 41:263-352.

Venette RC. 1997. Assessment of the Colonization Potential of Introduced Species During Biological Invasions. Ph.D. diss. University of California, Davis. $202 \mathrm{p}$.

Vermeij GJ. 1996. An agenda for invasion biology. Biological Conservation 78:3-9.

Williamson M. 1996. Biological Invasions. Chapman and Hall, New York. 244 p. 